\title{
PENGARUH GAYA KEPEMIMPINAN TERHADAP KINERJA PEGAWAI PADA KANTOR KECAMATAN GILIRENG KABUPATEN WAJO
}

\author{
MARYAM \\ Fakultas Agama Islam Universitas Indonesia Timur Makassar \\ Jl. Rappocini Raya No. 171-173 Kota Makassar 90222 \\ Email: maryam.mary7741@yahoo.com
}

\begin{abstract}
:
The goal to be achieved in this research is to know and analyze the influence of leadership style on employee performance. and to know and analyze the influence of leadership style on employee performance. The population in this study is the employees of the District Office Gilireng Wajo Regency amounting to 42 people. In the sample study, the authors used questionnaires from the population is all employees of District office Gilireng Wajo Regency amounting to 42 people. This study was conducted on the entire population, because the number of employees in the office is relatively small in number of as many as 42 employees. Based on the results of research shows leadership style has a significant influence on employee performance and gives a low effect on employee performance. Leadership style effect on employee performance At Gilireng District Office. That is, that to achieve more effective employee performance based on organizational goals and expectations then the leadership must pay attention to a good leadership style in order to improve skills and technical skills based on the function and task of an employee.
\end{abstract}

Keywords: Leadership Style, Employee Performance

\section{PENDAHULUAN}

aya kepemimpinan yang sesuai dengan keinginan instansi pemerintahan dan keinginan bawahan akan mendorong peningkatan kerja bagi pegawai. Karena kinerja yang baik akan dapat menunjang pencapaian sasaran dan tujuan instansi pemerintahan. Kepemimpinan yang diharapkan akan memberikan motivasi dan menerapkan disiplin kerja kepada pegawainya untuk menunjang pekerjaan di kantor Kecamatan Gilireng Kabupaten Wajo.

\section{PEMBAHASAN}

Karakteristik responden merupakan informasi yang sangat penting dan berguna bagi peneliti untuk mengetahui dan memahami identitas yang dimiliki responden. Informasi mengenai identitas responden terdiri atas; jenis kelamin, usia, dan jenjang pendidikan, merupakan informasi yang terkait dengan variabel dalam penelitian ini.

\section{Jenis Kelamin Responden}

Salah satu karakteristik responden yang memiliki daya tarik dan kekuatan untuk menghasilkan produktivitas kerja adalah jenis kelamin. Kedua jenis kelamin 
tersebut masing-masing kelebihan dan kekurangan baik sebagai pria maupun sebagai wanita. Ditinjau dari sudut power dan kekuatan otot (body) pria lebih kuat, agak kasar, egoistic, cepat mengambil keputusan, kurang memperhatikan perasaan dan sebagainya. Disisi lain wanita mempunyai kelebihan dan daya tarik tersendiri, feminim, terampil dalam mengerjakan sesuatu terutama yang memerlukan tingkat ketelitian, lebih banyak menggunakan perasaan dan sebagainya. Jumlah pegawai pria dan wanita yang menjadi responden dalam penelitian ini dilihat pada Table 1 di bawah ini.

Tabel 1. Jenis Kelamin Responden

\begin{tabular}{|c|c|c|c|}
\hline No. & Jenis Kelamin & Jumlah & Persentase \\
\hline 1. & Pria & 30 & $72,5 \%$ \\
\hline 2. & Wanita & 12 & $27,5 \%$ \\
\hline & Jumlah & 42 & $100 \%$ \\
\hline
\end{tabular}

Sumber : Hasil Penelitian

Berdasarkan pada Tabel 1 di atas menunjukkan bahwa jumlah pegawai pada Kantor Kecamatan Gilireng terdiri atas laki-laki sebanyak 30 orang (72,5\%) dan wanita sebanyak 12 orang (27,5\%). Masing-masing pegawai diberi tugas dan tanggung jawab sesuai kemampuan dan keterampilan yang dimilikinya.

\section{Tingkat Usia Responden}

Usia seseorang menggambarkan suatu tingkat kematangan dalam menerima dan melaksanakan tanggung jawab terkait dengan pekerjaan. Semakin matang usia seseorang semakin mampu memikul tanggung jawab yang dibebankan kepadanya. Oleh sebab itu usia dapat mempengaruhi tingkat kepuasan dan produktivitas kerja. Berbagai penelitian menunjukkan bahwa tingkat usia seseorang sangat menentukan efektivitas kerja semakin tua usia semakin menurun tingkat kemampuan baik secara fisik maupun psikis sedangkan kepuasan semakin tinggi. Tingkat usia responden dalam penelitian ini dapat dilihat pada Tabel 2 di bawah ini.

Tabel 2. Tingkat Usia Responden

\begin{tabular}{|c|c|c|}
\hline Kelompok Umur (thn) & Jumlah & Persentase \\
\hline $25-30$ & 8 & $19,05 \%$ \\
\hline $31-35$ & 10 & $23.80 \%$ \\
\hline $36-40$ & 13 & $30,95 \%$ \\
\hline $41-45$ & 6 & $14,29 \%$ \\
\hline $46-50$ & 5 & $11,9 \%$ \\
\hline Total responden & 42 & $100 \%$ \\
\hline
\end{tabular}

Sumber Data : Hasil Penelitian

Berdasarkan informasi Tabel 2 di atas menunjukkan bahwa rata-rata pegawai berada pada tingkat usia produktif. Hal ini menunjukkan bahwa sebesar apapun tanggungjawab yang diberikan akan mampu dilaksanakan dengan baik. Hal ini ditunjukan dalam Tabel 2 di atas dimana tingkat usia paling produktif berada 
antara kisaran umur 36 - 40 tahun. Jumlah pegawai yang berada posisi umur tersebut sekitar 13 orang (30,95\%). Dengan demikian kemampuan dan motivasi yang dimiliki cukup tinggi.

\section{Tingkat Pendidikan}

Pendidikan merupakan proses pembelajaran dan transformasi ilmu pengetahuan dalam rangka meningkatkan kemampuan pengetahuan baik yang bersifat umum maupun yang bersifat teknis. Semakin tinggi jenjang pendidikan yang dimiliki seseorang diindikasikan semakin tinggi pula pengetahuan yang dimilikinya. Untuk mengetahui jenjang pendidikan masing-masing responden dapat dilihat pada Tabel 3 di bawah ini.

Tabel 3. Tingkat Pendidikan Responden

\begin{tabular}{|c|c|c|}
\hline Jenis Pendidikan & Jumlah & Persentase \\
\hline SLTA & 4 & $9,5 \%$ \\
\hline Diploma & 12 & $28,6 \%$ \\
\hline Strata 1 & 20 & $47,6 \%$ \\
\hline Strata 2 & 6 & $14,3 \%$ \\
\hline Jumlah & 42 & 100 \\
\hline
\end{tabular}

Sumber Data: Hasil Penelitian

Berdasarkan Tabel 3 di atas menunjukkan bahwa tingkat pendidikan responden adalah berada diatas jejang pendidikan SLTA sebanyak 4 orang atau sekitar 9,5\%. Dimana Pendidikan Diploma sebanyak 12 orang atau sekitar 28,6\%, pendidikan Strata 1 sebanyak 20 orang atau sekitar 47,6 \%. Sedangkan untuk strata 2 sebanyak 6 orang atau sekitar 14,3\%. Ini menunjukkan bahwa sumberdaya yang dimiliki oleh perusahaan merupakan sumber daya yang handal yang memliki pengetahuan dan pemahaman .

\section{Jawaban Responden terhadap Kuesioner Gaya Kepemimpinan.}

Berdasarkan kuesioner yang telah dibagikan kepada responden (pegawai Kantor Kecamatan Gilireng) maka dapat diketahui hasil jawaban atas pertanyaan yang diajukan kepada responden menyangkut masalah gaya kepemimpinan. Berikut ini disajikan tabel jawaban responden.

\begin{tabular}{|c|c|c|c|c|c|c|c|c|c|c|c|}
\hline \multirow{2}{*}{ Responden } & \multicolumn{10}{|c|}{ PERTANYAAN } & \multirow{2}{*}{ Rata Rata } \\
\cline { 2 - 12 } & I & II & III & IV & V & VI & VII & VIII & IX & X & \\
\hline 1 & 5 & 5 & 5 & 5 & 5 & 5 & 5 & 5 & 5 & 5 & 5 \\
\hline 2 & 5 & 4 & 3 & 4 & 5 & 4 & 4 & 4 & 3 & 4 & 4 \\
\hline 3 & 5 & 5 & 5 & 5 & 5 & 5 & 5 & 5 & 5 & 5 & 5 \\
\hline 4 & 5 & 5 & 5 & 5 & 5 & 5 & 5 & 5 & 5 & 5 & 5 \\
\hline 5 & 4 & 4 & 5 & 5 & 4 & 3 & 3 & 5 & 3 & 4 & 4 \\
\hline 6 & 5 & 5 & 5 & 5 & 5 & 5 & 5 & 5 & 5 & 5 & 5 \\
\hline 7 & 5 & 5 & 5 & 5 & 5 & 5 & 5 & 5 & 5 & 5 & 5 \\
\hline 8 & 4 & 4 & 4 & 3 & 5 & 5 & 4 & 3 & 5 & 3 & 4 \\
\hline
\end{tabular}


PENGARUH GAYA KEPEMIMIPINAN TERHADAP KINERJA PEGAWAI ...

\begin{tabular}{|c|c|c|c|c|c|c|c|c|c|c|c|}
\hline 9 & 5 & 5 & 5 & 5 & 5 & 5 & 5 & 5 & 5 & 5 & 5 \\
\hline 10 & 3 & 3 & 4 & 4 & 3 & 4 & 5 & 4 & 5 & 5 & 4 \\
\hline 11 & 5 & 5 & 5 & 5 & 5 & 5 & 5 & 5 & 5 & 5 & 5 \\
\hline 12 & 4 & 4 & 5 & 4 & 5 & 4 & 4 & 3 & 3 & 4 & 4 \\
\hline 13 & 5 & 5 & 5 & 5 & 5 & 5 & 5 & 5 & 5 & 5 & 5 \\
\hline 14 & 5 & 5 & 5 & 5 & 5 & 5 & 5 & 5 & 5 & 5 & 5 \\
\hline 15 & 5 & 5 & 5 & 5 & 5 & 5 & 5 & 5 & 5 & 5 & 5 \\
\hline 16 & 5 & 5 & 5 & 5 & 5 & 5 & 5 & 5 & 5 & 5 & 5 \\
\hline 17 & 5 & 4 & 3 & 4 & 3 & 5 & 4 & 4 & 5 & 3 & 4 \\
\hline 18 & 4 & 4 & 4 & 4 & 4 & 4 & 4 & 4 & 4 & 4 & 4 \\
\hline 19 & 5 & 5 & 5 & 5 & 5 & 5 & 5 & 5 & 5 & 5 & 5 \\
\hline 20 & 4 & 4 & 4 & 3 & 5 & 5 & 4 & 3 & 5 & 3 & 4 \\
\hline 21 & 5 & 5 & 5 & 5 & 5 & 5 & 5 & 5 & 5 & 5 & 5 \\
\hline 22 & 5 & 5 & 5 & 5 & 5 & 5 & 5 & 5 & 5 & 5 & 5 \\
\hline 23 & 5 & 5 & 5 & 5 & 5 & 5 & 5 & 5 & 5 & 5 & 5 \\
\hline 24 & 4 & 4 & 4 & 3 & 5 & 5 & 4 & 3 & 5 & 3 & 4 \\
\hline 25 & 5 & 5 & 5 & 5 & 5 & 5 & 5 & 5 & 5 & 5 & 5 \\
\hline 26 & 4 & 4 & 4 & 3 & 5 & 5 & 4 & 3 & 5 & 3 & 4 \\
\hline 27 & 5 & 5 & 5 & 5 & 5 & 5 & 5 & 5 & 5 & 5 & 5 \\
\hline 28 & 5 & 5 & 5 & 5 & 5 & 5 & 5 & 5 & 5 & 5 & 5 \\
\hline 29 & 5 & 5 & 5 & 5 & 5 & 5 & 5 & 5 & 5 & 5 & 5 \\
\hline 30 & 5 & 5 & 5 & 5 & 5 & 5 & 5 & 5 & 5 & 5 & 5 \\
\hline 31 & 4 & 4 & 4 & 3 & 5 & 5 & 4 & 3 & 5 & 3 & 4 \\
\hline 32 & 5 & 5 & 5 & 5 & 5 & 5 & 5 & 5 & 5 & 5 & 5 \\
\hline 33 & 5 & 5 & 5 & 5 & 5 & 5 & 5 & 5 & 5 & 5 & 5 \\
\hline 34 & 4 & 4 & 4 & 3 & 5 & 5 & 4 & 3 & 5 & 3 & 4 \\
\hline 35 & 5 & 5 & 5 & 5 & 5 & 5 & 5 & 5 & 5 & 5 & 5 \\
\hline 36 & 4 & 4 & 4 & 3 & 5 & 5 & 4 & 3 & 5 & 3 & 4 \\
\hline 37 & 5 & 5 & 5 & 5 & 5 & 5 & 5 & 5 & 5 & 5 & 5 \\
\hline 38 & 5 & 5 & 5 & 5 & 5 & 5 & 5 & 5 & 5 & 5 & 5 \\
\hline 39 & 3 & 3 & 4 & 4 & 3 & 4 & 5 & 4 & 5 & 5 & 4 \\
\hline 40 & 5 & 5 & 5 & 5 & 5 & 5 & 5 & 5 & 5 & 5 & 5 \\
\hline 41 & 3 & 3 & 4 & 4 & 3 & 4 & 5 & 4 & 5 & 5 & 4 \\
\hline 42 & 5 & 5 & 5 & 5 & 5 & 5 & 5 & 5 & 5 & 5 & 5 \\
\hline
\end{tabular}

Sumber: Data diolah

Keterangan :

5 = Sangat Setuju

$4=$ Setuju

3 = Ragu-ragu

2 = Tidak setuju

1 = Sangat tidak setuju

Berdasarkan Tabel 4 di atas menunjukkan bahwa sebanyak 27 orang responden sangat setuju sedangkan 15 orang responden memberikan jawaban 
setuju, hal ini berarti tingkat kepuasan responden atas gaya kepemimpinan sangat baik.

\section{Jawaban Responden terhadap Kuesioner Kinerja.}

Berdasarkan kuesioner yang telah dibagikan kepada responden (pegawai Kantor Kecamatan Gilireng) maka dapat diketahui hasil jawaban atas pertayaan yang diajukan kepada responden menyangkut masalah kinerja pegawai . Berikut ini disajikan tabel jawaban responden.

\begin{tabular}{|c|c|c|c|c|c|c|c|c|c|c|c|}
\hline \multirow{2}{*}{ Responden } & \multicolumn{10}{|c|}{ PERTANYAAN } & \multirow{2}{*}{ Rata Rata } \\
\hline & I & II & III & IV & V & VI & VII & VIII & IX & $X$ & \\
\hline 1 & 4 & 4 & 2 & 3 & 3 & 2 & 3 & 3 & 2 & 3 & 3 \\
\hline 2 & 5 & 5 & 5 & 5 & 5 & 5 & 5 & 5 & 5 & 5 & 5 \\
\hline 3 & 3 & 4 & 3 & 3 & 3 & 3 & 2 & 3 & 3 & 3 & 3 \\
\hline 4 & 5 & 4 & 4 & 3 & 5 & 4 & 3 & 4 & 4 & 4 & 4 \\
\hline 5 & 3 & 3 & 3 & 3 & 4 & 3 & 3 & 2 & 3 & 3 & 3 \\
\hline 6 & 3 & 4 & 3 & 3 & 3 & 3 & 2 & 3 & 3 & 3 & 3 \\
\hline 7 & 3 & 4 & 3 & 3 & 3 & 3 & 2 & 3 & 3 & 3 & 3 \\
\hline 8 & 5 & 4 & 4 & 3 & 5 & 4 & 3 & 4 & 4 & 4 & 4 \\
\hline 9 & 3 & 4 & 4 & 5 & 4 & 4 & 4 & 3 & 4 & 5 & 4 \\
\hline 10 & 5 & 4 & 4 & 3 & 5 & 4 & 3 & 4 & 4 & 4 & 4 \\
\hline 11 & 3 & 3 & 5 & 2 & 4 & 3 & 3 & 3 & 2 & 3 & 3 \\
\hline 12 & 3 & 3 & 3 & 3 & 3 & 3 & 3 & 3 & 3 & 3 & 3 \\
\hline 13 & 4 & 3 & 5 & 3 & 4 & 4 & 4 & 5 & 4 & 4 & 4 \\
\hline 14 & 3 & 2 & 4 & 3 & 3 & 3 & 3 & 3 & 3 & 3 & 3 \\
\hline 15 & 4 & 4 & 4 & 4 & 4 & 4 & 4 & 4 & 4 & 4 & 4 \\
\hline 16 & 4 & 4 & 3 & 3 & 2 & 3 & 3 & 3 & 3 & 2 & 3 \\
\hline 17 & 3 & 3 & 3 & 3 & 3 & 3 & 3 & 3 & 3 & 3 & 3 \\
\hline 18 & 3 & 3 & 2 & 2 & 2 & 2 & 1 & 1 & 2 & 2 & 2 \\
\hline 19 & 3 & 3 & 3 & 3 & 3 & 3 & 3 & 3 & 3 & 3 & 3 \\
\hline 20 & 4 & 4 & 3 & 2 & 3 & 2 & 3 & 3 & 3 & 3 & 3 \\
\hline 21 & 3 & 3 & 3 & 3 & 3 & 3 & 3 & 4 & 2 & 3 & 3 \\
\hline 22 & 3 & 3 & 3 & 3 & 3 & 3 & 3 & 3 & 3 & 3 & 3 \\
\hline 23 & 4 & 2 & 4 & 3 & 3 & 3 & 3 & 3 & 2 & 3 & 3 \\
\hline 24 & 2 & 2 & 2 & 3 & 3 & 3 & 4 & 4 & 3 & 4 & 3 \\
\hline 25 & 3 & 3 & 3 & 3 & 3 & 3 & 3 & 3 & 3 & 3 & 3 \\
\hline 26 & 3 & 3 & 3 & 3 & 3 & 3 & 3 & 3 & 3 & 3 & 3 \\
\hline 27 & 4 & 3 & 3 & 3 & 2 & 4 & 2 & 3 & 3 & 3 & 3 \\
\hline 28 & 4 & 4 & 4 & 4 & 4 & 4 & 4 & 4 & 4 & 4 & 4 \\
\hline 29 & 3 & 3 & 3 & 3 & 3 & 3 & 3 & 3 & 3 & 3 & 3 \\
\hline 30 & 5 & 4 & 4 & 4 & 3 & 3 & 5 & 4 & 4 & 4 & 4 \\
\hline 31 & 3 & 3 & 2 & 2 & 2 & 2 & 1 & 1 & 2 & 2 & 2 \\
\hline 32 & 3 & 3 & 3 & 3 & 3 & 3 & 3 & 3 & 3 & 3 & 3 \\
\hline 33 & 4 & 3 & 5 & 3 & 4 & 4 & 4 & 5 & 4 & 4 & 4 \\
\hline
\end{tabular}




\begin{tabular}{|l|l|l|l|l|l|l|l|l|l|l|l|}
\hline 34 & 3 & 2 & 4 & 3 & 3 & 3 & 3 & 3 & 3 & 3 & 3 \\
\hline 35 & 4 & 4 & 4 & 4 & 4 & 4 & 4 & 4 & 4 & 4 & 4 \\
\hline 36 & 4 & 4 & 3 & 3 & 2 & 3 & 3 & 3 & 3 & 2 & 3 \\
\hline 37 & 3 & 3 & 3 & 3 & 3 & 3 & 3 & 3 & 3 & 3 & 3 \\
\hline 38 & 3 & 3 & 3 & 3 & 3 & 3 & 3 & 3 & 3 & 3 & 3 \\
\hline 39 & 4 & 3 & 3 & 3 & 2 & 4 & 2 & 3 & 3 & 3 & 3 \\
\hline 40 & 5 & 4 & 4 & 3 & 5 & 4 & 3 & 4 & 4 & 4 & 4 \\
\hline 41 & 4 & 3 & 3 & 3 & 2 & 4 & 2 & 3 & 3 & 3 & 3 \\
\hline 42 & 5 & 4 & 4 & 3 & 5 & 4 & 3 & 4 & 4 & 4 & 4 \\
\hline
\end{tabular}

Sumber : data diolah

Keterangan:

5 = Sangat Setuju

$4=$ Setuju

3 = Ragu-ragu

2 = Tidak setuju

1 = Sangat tidak setuju

Berdasarkan Tabel 4 di atas menunjukkan bahwa sebanyak 1 orang responden sangat setuju, 12 orang responden memberikan jawaban setuju, 27 orang responden menjawab ragu-ragu sedangkan 2 orang responden menjawab tidak setuju. Hal ini berarti tingkat kepuasan responden atas Kinerja masih belum optimal.

\section{HASIL PENELITIAN}

Kepemimpinan kepala Kantor Kecamatan Gilireng yang mampu mengintegrasikan organisasi dengan berbagai tuntutan dan kebutuhan masyarakat. Kenyataan ini dibuktikan oleh Pimpinan dalam setiap penanganan organisasi dengan memperlakukan seluruh satuan kerja dalam organisasi, dengan persepsi dan pendekatan yang holistik, bukan dengan persepsi dan pendekatan inkrementalistik, apalagi yang atomistik dalam mencapai visi dan misi organisasi. Oleh karena itu, tidak ada yang keliru apabila karena latar belakang pendidikan dan pengalamannya, seorang pemimpin memiliki pengetahuan yang spesialistik. Namun, pengetahuan yang spesialistik itu hanya akan menjadi penghalang bagi efektifitas kepemimpinan dalam mengintegrasikan organisasi, jika ia tidak mampu berpikir generalis terhadap seluruh satuan kerjanya untuk tidak bekerja sendirisendiri dalam menghadapi tuntutan kebutuhan masyarakat. Hanya saja perhatian demikian cukup diberikan oleh para pejabat pimpinan yang berada pada bagian bawah dari hirarkhi kepemimpinan dalam organisasi, yang memang dituntut memiliki pengetahuan yang spesialistik.

Oleh sebab itu, peranan para ahli strategi di sini disebut sebagai integrator role. Integrator role merupakan kenyataan dalam kehidupan bahwa timbulnya 
kecenderungan berpikir dan bertindak berkotak-kotak dikalangan para anggota organisasi dapat diakibatkan oleh sikap yang positif, tetapi mungkin pula karena sikap yang negatif. Dikatakan dapat bersifat positif, karena adanya tekad dan kemauan keras dikalangan para anggota organisasi, yang tergabung dalam satu kelompok tertentu untuk berbuat seoptimal mungkin bagi organisasi. Akan tetapi, sikap demikian dapat mempunyai dampak negatif bagi kehidupan organisasional, apabila dalam usaha berbuat sebaik mungkin bagi organisasi, para anggota organisasi yang bersangkutan lupa bahwa keberhasilan satu kelompok yang bekerja sendiri belum menjamin keberhasilan organisasi secara keseluruhan.

Kepemimpinan kepala Kantor Kecamatan Gilireng telah berusaha mempertanggungjawabkan kepemimpinannya dalam tubuh organisasi, termasuk bagaimana Pimpinan mengembangkan kemampuan sumberdaya manusia secara internal, untuk mewujudkan dan menunjang pemerintahan yang efektif dan efisien. Disinilah fungsi kepemimpinan sebagai The Competence Role, yakni pertanggungjawaban ahli strategi dalam tubuh organisasi.

Untuk mengetahui pengaruh gaya kepemimpinan terhadap kinerja pegawai pada Kantor Kecamatan Gilireng, penulis menggunakan analisis koefisien regresi linear. Adapun rumus analisis regresi linear menurut Suharyadi (2014 : 207) sebagai berikut :

$$
Y=a+b x
$$

Dimana :

$Y=$ Volume Penjualan

$\mathrm{a}=$ Konstanta

$\mathrm{b}=$ Koefisien

$\mathrm{X}=$ Biaya Promosi

Parameter a dan b digunakan persamaan :

$$
b=\frac{n(\Sigma X Y)-(\Sigma X \Sigma Y)}{n\left(\Sigma X^{2}\right)-(\Sigma X)^{2}}
$$

$a=\underline{\Sigma Y-b(X)}$

$n$

Berdasarkan rumus di atas, maka untuk mengaplikasikan rumus diatas terlebih dahulu dibuat tabel korelasi seperti terlihat pada tabel berikut ini:

Tabel Regresi dan Koefesieen Korelasi TerhadapGaya Kepemimpinan dan Kinerja Pegawai PadaKantor Kecamatan Gilireng

\begin{tabular}{|c|c|c|c|c|c|}
\hline \hline Responden & $\begin{array}{c}\text { Gaya } \\
\text { Kepemimpinan } \\
(\mathrm{X})\end{array}$ & $\begin{array}{c}\text { Kinerja } \\
\text { Pegawai } \\
(\mathrm{Y})\end{array}$ & $\mathrm{X}^{2}$ & $\mathrm{Y}^{2}$ & $\mathrm{XY}$ \\
\hline \hline 1 & 5 & 3 & 25 & 9 & 15 \\
\hline 2 & 4 & 5 & 16 & 25 & 20 \\
\hline
\end{tabular}


PENGARUH GAYA KEPEMIMIPINAN TERHADAP KINERJA PEGAWAI ...

\begin{tabular}{|c|c|c|c|c|c|}
\hline 3 & 5 & 3 & 25 & 9 & 15 \\
\hline 4 & 5 & 4 & 25 & 16 & 20 \\
\hline 5 & 4 & 3 & 16 & 9 & 12 \\
\hline 6 & 5 & 3 & 25 & 9 & 15 \\
\hline 7 & 5 & 3 & 25 & 9 & 15 \\
\hline 8 & 4 & 4 & 16 & 16 & 16 \\
\hline 9 & 5 & 4 & 25 & 16 & 20 \\
\hline 10 & 4 & 4 & 16 & 16 & 16 \\
\hline 11 & 5 & 3 & 25 & 15 & 15 \\
\hline 12 & 4 & 3 & 16 & 9 & 12 \\
\hline 13 & 5 & 4 & 25 & 16 & 20 \\
\hline 14 & 5 & 3 & 25 & 9 & 15 \\
\hline 15 & 5 & 4 & 25 & 16 & 20 \\
\hline 16 & 5 & 3 & 25 & 9 & 15 \\
\hline 17 & 4 & 3 & 16 & 9 & 12 \\
\hline 18 & 4 & 2 & 16 & 4 & 8 \\
\hline 19 & 5 & 3 & 25 & 9 & 15 \\
\hline 20 & 4 & 3 & 16 & 9 & 12 \\
\hline 21 & 5 & 3 & 25 & 9 & 15 \\
\hline 22 & 5 & 3 & 25 & 9 & 15 \\
\hline 23 & 5 & 3 & 25 & 9 & 15 \\
\hline 24 & 4 & 3 & 16 & 9 & 12 \\
\hline 25 & 5 & 3 & 25 & 9 & 15 \\
\hline 26 & 4 & 3 & 16 & 9 & 12 \\
\hline 27 & 5 & 3 & 25 & 9 & 15 \\
\hline 28 & 5 & 4 & 25 & 16 & 20 \\
\hline 29 & 5 & 3 & 16 & 9 & 15 \\
\hline 30 & 5 & 4 & 25 & 16 & 20 \\
\hline 31 & 4 & 2 & 16 & 4 & 8 \\
\hline 32 & 5 & 3 & 15 & 9 & 15 \\
\hline 33 & 5 & 4 & 25 & 16 & 20 \\
\hline 34 & 4 & 3 & 16 & 9 & 12 \\
\hline 35 & 5 & 4 & 25 & 16 & 20 \\
\hline 36 & 4 & 3 & 16 & 9 & 12 \\
\hline 37 & 5 & 3 & 25 & 9 & 15 \\
\hline 38 & 5 & 3 & 25 & 9 & 15 \\
\hline 39 & 4 & 3 & 16 & 9 & 12 \\
\hline 40 & 5 & 4 & 25 & 16 & 20 \\
\hline 41 & 4 & 3 & 16 & 9 & 12 \\
\hline 42 & 5 & 4 & 25 & 16 & 20 \\
\hline$N=42$ & $\sum x=195$ & $\sum y=138$ & $\sum x^{2}=896$ & $\sum y^{2}=474$ & $\sum x y=611$ \\
\hline
\end{tabular}

Sumber : data diolah 


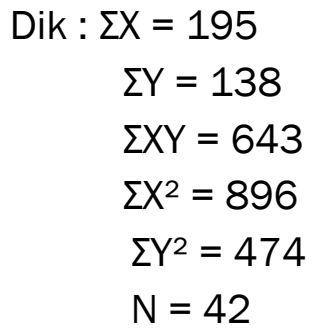

Berdasarkan data pada tabel di atas, maka dapat dihitung nilai b yaitu

$$
\begin{aligned}
& b=\underline{n(\Sigma X Y)-(\Sigma X . \Sigma Y)} \\
& n\left(\Sigma X^{2}\right)-(\Sigma X)^{2} \\
& b=\underline{42(643)-(195 \times 138)} \\
& 42(896)-(195)^{2} \\
& =\underline{27.006-26.910} \\
& 37.632-38.025 \\
& =\underline{96} \\
& -393 \\
& b=-0,24
\end{aligned}
$$

Untuk menentukan parameter a dapat dihitung dengan menggunakan persamaan:

$$
\begin{aligned}
& a=\underline{\Sigma Y}-b(X) \\
& n \\
& a=138-(-0,24) \cdot(195) \\
& 42
\end{aligned}
$$$$
a=\underline{138-(-46,8)}
$$$$
42
$$$$
\mathrm{a}=\underline{184.8}
$$$$
42
$$$$
a=4,4
$$$$
y=4,4-0,24 x
$$

Jadi berdasarkan perhitungan di atas, maka persamaan regresi adalah $\mathrm{Y}=$ 4,4 - 0,24x. Hasil perhitungan diatas dapat dijelaskan bahwa nilai konstanta sebesar 4,4 menunjukkan bahwa dengan adanya variabel $X$ (gaya kepemimpinan) maka nilai variabel Y (Kinerja Pegawai ) akan naik pula sebesar 4,4, namun jika sebaliknya variabel $X=0$ maka akan menurunkan nilai variabel $y=0,24$. Angka koefesien $x=0,24$ menununjukkan bahwa setiap peningkatan gaya kepemimpinan sebesar 0,01 akan menurungkan kinerja pegawai. 
Untuk mengetahui tingkat korelasi atau keeratan hubungannya antara gaya kepemimpinan dengan kinerja pegawai pada Kantor Kecamatan Gilireng, maka penulis menganalisis menggunakan rumus korelasi sebagai berikut :

$$
r=\frac{n \sum X Y-\left(\sum X\right)\left(\sum Y\right)}{\sqrt{n \sum X^{2}-(X)^{2} \sqrt{n \sum_{Y} 2-\left(\sum_{Y}\right)^{2}}}}
$$

Koefisien korelasi mendekati satu kenyataan kuat hubungan ketergantungannya atau signifikan.

Selanjutnya dengan berdasarkan tabel diatas, dapat dicari koefisien korelasi dengan cara :

Dik : $\Sigma X=195$

$\Sigma Y=138$

$\Sigma X Y=611$

$\Sigma X^{2}=896$

$\Sigma Y^{2}=474$

$\mathrm{N}=42$

$r=\frac{n \sum X Y-\left(\sum X\right)\left(\sum Y\right)}{\sqrt{n \sum X^{2}-(X)^{2} \sqrt{n \sum_{Y}^{2}-\left(\sum_{Y}\right)^{2}}}}$

$42(611)-(195 \times 138)$

$r=$

$\left(\sqrt{ } 42(896)-(195)^{2}\right) \cdot\left(\sqrt{ } 42(474)-(138)^{2}\right)$

$r=$

(25.662) - (25.910)

$(\sqrt{ } 37.632-38.025) \cdot(\sqrt{ } 19.908-19.044)$

$r=$

$(-248)$

$(\sqrt{ }-393 \sqrt{ } 864)$

$(-248)$

$r=$

$(19,82 \times 29,39)$

$(-248)$

$r=$

( 582 )

$r=\quad-0,42$

$r^{2}=-0.017$ 
Berdasarkan hasil perhitungan koefisien korelasi $r=-0,42$ atau atau berada di daerah negatif, ini menunjukkan bahwa antara gaya kepemimpinan dengan kinerja pegawainegatif dan bersifat tidak searah, artinya bahwa penurunan nilai x (gaya kepemimpinan)terjadi bersama penurunan nilai y (kinerja pegawai), demikian pula sebaliknya.Keeratan hubungan antara gaya kepemimpinan dengan kinerja pegawai adalah sebesar $-0,42$ atau 4,2 \%. Tanda negatif pada koefisien korelasi menunjukkan ada hubungan tidak searah namun hubungan korelasinya rendah, artinya apabila terjadinya penurunan gaya kepemimpinan akan mempengaruhi penurunan kinerja pegawai .

Berdasarkan hasil analisis diperoleh nilai koefisien korelasi ( $R$ ) sebesar 0,42. Nilai koefisien korelasi tersebut signifikan pada taraf signifikansi 0,05 ini menunjukan bahwa "terdapat hubungan yang negatif antara gaya kepemimpinan dengan kinerja pegawai pada Kantor Kecamatan Gilireng, sehingga hipotesis awal yang menyatakan bahwa gaya kepemimpinan berpengaruh terhadap kinerja pegawai di tolak. Nilai Koefisien korelasi 0,42 juga menunjukkan bahwa indeks kuatnya hubungan korelasi $X$ (gaya kepemimpinan) terhadap $Y$ (Kinerja pegawai) berada dalam kategori sangat rendah. Hal ini sejalan dengan apa yang dikemukakan atau menggunakan pedoman untuk memberikan interpretasi koefisien korelasi menurut Sugiyono (2000) sebagai berikut:

\begin{tabular}{|c|c|c|}
\hline Interval & & Tingkat hubungan \\
\hline $0,00-0,199$ & $:$ & Sangat rendah \\
\hline $0,20-0,399$ & $:$ & Rendah \\
\hline $0,40-0,599$ & $:$ & Sedang \\
\hline $0,60-0,799$ & $:$ & Kuat \\
\hline $0,80-1,000$ & $:$ & Sangat Kuat \\
\hline
\end{tabular}

Koefisien Determinasi $\left(\mathrm{r}^{2}\right)$ adalah 0,017 artinya besarnya pengaruh gaya kepemimpinan terhadap kinerja pegawai adalah sebesar $17 \%$. Dan sisanya sebesar $83 \%$ merupakan pengaruh variabel bebas lainnya yang tidak dibahas dalam penelitian ini.

\section{KESIMPULAN}

Berdasarkan hasil penelitian dan pembahasan yang telah di kemukakan sebelumnya, maka dapatlah ditarik beberapa kesimpulan sebagai berikut:

1. Berdasarkan hasil penelitian menunjukkan gaya kepemimpinan mempunyai pengaruh signifikan terhadap kinerja pegawai dan memberikan pengaruh yang rendah terhadap kinerja pegawai.

2. Gaya kepemimpinan berpengaruh terhadap kinerja pegawai Pada Kantor Kecamatan Gilireng. Artinya, bahwa untuk mencapai kinerja pegawai yang lebih efektif berdasarkan tujuan dan harapan organisasi maka pimpinan harus memperhatikan gaya kepemimpinan yang baik agar dapat meningkatkan 
kemampuan dan keterampilan teknis berdasarkan fungsi dan tugas pokok seorang pegawai.

\section{DAFTAR PUSTAKA}

Adryanto, Michael "Mengenali Metode Penelitian 360 derajat" Artikel diakses dari http://michaeladryanto.wordpress.com/2011/11/09/ mengenalimetodepenelitian-360-derajat/

Bangun, Wilson. “Manajemen Sumber Daya Manusia”. Erlangga, Bandung, 2012.

Gusti, Media, Messa. "Pengaruh Kedisiplinan, Motivasi Kerja dan Persepsi Guru tentang Kepemimpinan Kepala Sekolah terhadap Kinerja Guru SMKN 1 Purworejo Pasca Sertifikasi" 2012.

Hakim, Lukmanul. "Pengaruh Gaya Kepemimpinan terhadap Kinerja Pegawai Negeri Sipil Melalui Motivasi pada Dinas Perhubungan Kota Palembang”. Volume III. No. 3, 2011.

Hamid, Abdul. "Buku Panduan Penulisan Skripsi” UN Jakarta 2010.

Hasibuan, S.P. Melayu. "Manajemen Sumber Daya Manusia” Bumi Aksara, edisi ketiga.Jakarta, 2012.

Kartono, Kartini “Pemimpin dan Kepemimpinan" Raja Grafindo Persada, Jakarta, 2008.

Kreitner, Robert dan Angelo, Knicki. "Perilaku Organisasi” Jilid 2, Salemba Empat, Jakarta, 2005.

Mangkunegara Anwar Prabu. "Manajemen Sumber Daya Manusia". Rosdakarya, Bandung,2010.

Mathis, L. Robert dan Jackson, John H., “Manajemen Sumber Daya Manusia” Jilid 1, Salemba Empat, Jakarta, 2009.

Mulyono. "Pengaruh Kesesuaian Kompentensi dan Motivasi terhadap Kinerja Pegawai Negeri Sipil Bagian Administrasi pada Sekolah Menengah Atas Negeri Kota Malang”. Jurnal Manajemen dan Akuntansi. Vol. 1, No. 1, 2012.

Murray, Adela, Islam, Mazharul, Sarros, James and Andrew."The Impact of Leadership on Work group Climate and Performance ina Non-Profit Organization", Development Journal, Vol.33, No.6, 2012.

Prasetyo, lis.“ Pengaruh Gaya Kepemimpinan terhadap Kinerja” .Jurnal Neo Bisnis, Vol. 2, No .2, 2008.

Prawatya, Adi, Dipta dan Raharjo, Toto, Susilo. “Pengaruh Disiplin Kerja dan Budaya Organisasi terhadap Kinerja Karyawan Pabrik Minyak Kayu Putih (PMKP) dl Krai Purwodadi”. Diponegoro Journal of Management. Volume 1, No. 1, 2012. Robbins, Stephen P. “Perilaku Organisasi“, Jilid 1, Prehallindo, Jakarta, 2001. 
Rochaey Ety Tresnati, Ratih. Madjid Latief, Abdul. "Metodologi Penelitian Bisnis: Dengan Aplikasi SPSS” Edisi Revisi Jakarta Mitra Wacana Media, 2009.

Sedarmayanti "Manajemen Sumber Daya Manusia dan Produktifitas Kerja". Mandar Maju, Bandung, 2011.

Sofat, Surbhi. "Effect of Motivation on Employee Performance and Organizational Productivity".Journal of Applied Management \& Computer Science, Vol.1, 2012.

Sopiah, Andi. "PerilakuOrganisasi” Yogyakarta, 2008.

Sriwidadi, Teguh dan Oey Charlie."Analisis Pengaruh Gaya Kepemimpinan terhadap Kinerja SPGPD. Sumber Jaya” Jurnal Bisnis Review,Vol. 2, No. 1, Mei 2011.

Sugyono. "Metode Penelitian Bisnis" Bandung Alfabeta, 2008.

Sutrisno, Edi. “Manajemen Sumber Daya Manusia” Edisi Pertama, Jakarta: Kencana Prenda Media Group, 2007.

Thoha Miftah. “Kepemimpinan dalam Manajemen” Jakarta: Raja Grafindo Persada, 2010.

Yoga Kusuma Wardana, Pengaruh Gaya Kepemimpinan, Motivasi Dan Disiplin Kerja Terhadap Kinerja (Studi Kasus pada Kantor Kecamatan Cisauk Kabupaten Tangerang), Fakultas Ekonomi Dan Bisnis Universitas Islam Negeri Syarif Hidayatullah Jakarta 2014

Umam, Khaeul. “Perilaku Organisasi” Pustaka Setia Bandung, 2010.

Veithzal, Rivai dan Ella Jauvani Sagala.“Manajemen Sumber Daya Manusia untuk Perusahaan" Cetakan ke3, Jakarta:Rajawali Pers, 2010.

Veithzal, Rivai. “Manajemen Sumber Daya Manusia untuk Perusahaan”.Jakarta: Raja Grafindo Persada, 2009.

Winardi, J “Manajemen Perilaku Organisasi”. Prenda MediaGroup, Jakarta.

Wirawan. "Evaluasi Kinerja, Sumber Daya Manusia, Teori Aplikasi dan Penelitian" Salemba Empat, Jakarta, 2009. 